\title{
Overview of the Black Garlic Movement in the Fields of Research and Marketing
}

\author{
Jin-Ichi Sasaki \\ Department of Emergency Medical Technology, Hirosaki University of Health and Welfare Junior College, Hirosaki 036-8104, Japan
}

Received: February 13, 2015 / Accepted: February 28, 2015 / Published: February 28, 2015.

\begin{abstract}
Newly developed black garlic had made a sensational debut with a strong anti-tumor potency proved by the mouse tumor model in 2006 from our laboratory. At that time few researches on it have been conducted due to less popularity of the products even among the researching field. Since then some of the bio-functional works of the black garlic gradually appeared along with gaining of its popularity. Representative bio-activities reported up to now are: (1) enhancement of anti-tumor potency in the mouse tumor model; (2) immune system enforcement, and suppressive act against allergic symptoms caused by decreasing IL-4 cytokine production; (3) bacteria killing potency; (4) anti-oxidant activity; (5) reduction of carcinogenic potency; (6) lowering cholesterol level and preventive work against obesity; (7) controlling high blood pressure; (8) beneficial effect against diabetics; (9) regenerative effect to the burned skin (Clinical study case) et al. On the black garlic business (marketing), the Aomori Black Garlic Union (Association) had been established in Aomori Prefecture to offer the citizen high quality, high safety and high security black garlic (products) aiming at contribution for health improvement. All union members are now exerting themselves to the most to attain the high quality production of the black garlic. The quality proving certification seal will be issued to the products that passed the quality approval test by the third party inspections to place it on the their products. This system is now effectively working to guarantee the garlic quality and differentiate the Union member's products from others at the markets.
\end{abstract}

Key words: Black garlic, anti-tumor potency, anti-oxidant activity, anti-bacterial act, black garlic union, quality approval test.

\section{Introduction}

Citizen's upsurge of interest is now toward the functional foods with possible expectation to decrease incidence of the lifestyle-related diseases by the functions of the foods. The Ministry of Health and Welfare in Japan has lately stated that the modification of the daily diet style can lower the incidence of variety of lifestyle-related diseases, eventually large reduction of the government annual budget.

In 1999, the miracle vegetable with multi-biological functions "Black garlic" was created by Japanese Mr. Kamimura in Mie prefecture Japan [1], being characteristic with sweet taste as a fruit, no pungent odor, and directly edible just after peeling off outer

Corresponding author: Jin-Ichi Sasaki, Ph.D., professor, research fields: microbiology, immunology, cancer immunotherapy, food function. E-mail: sasakij@jyoto-gakuen.ac.jp. coat. It was really a revolution in the field of vegetable and food world.

The number of the black garlic companies now reaches over 500 just in Japan, and some of them expand their business in building of black garlic making plants in foreign countries. The black garlic is easily creating just by controlling of temperature and humidity with no use of additives in the conditioned circumstances.

In 2006 we had first demonstrated presence of the strong anti-tumor potency in the black garlic using a mouse tumor model (Fig. 1). This report had much accelerated the people's healthy preference with hope that they could control their health conditions just by ingesting this miracle vegetable-black garlic.

Almost ten years have passed since the black garlic function had been introduced in the newspaper, the author overviewed the worldwide movements of the 


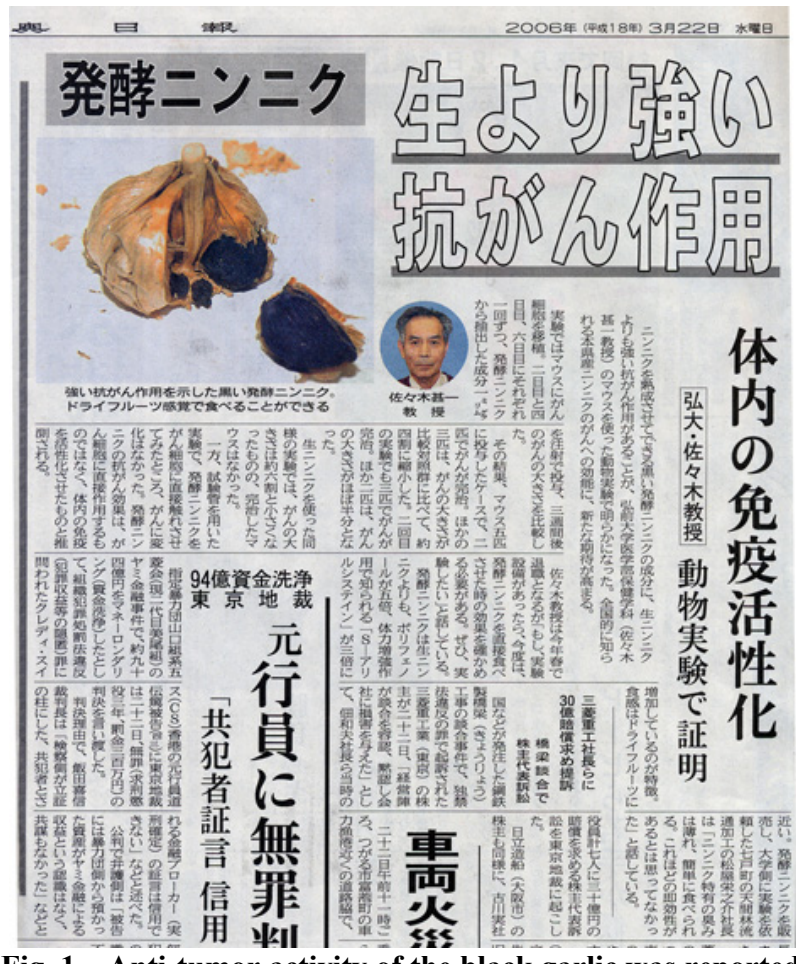

Fig. 1 Anti-tumor activity of the black garlic was reported in Newspaper on the Mutsu Shinpo, March 22, 2006.

black garlic from both aspects of researches and new business in this paper.

\section{Historical Background of the Black Garlic}

Concerning history of the black garlic appeared on the home page of Web site [2], it is described likely

"Black garlic has gained popularity in Japan after a research showing its health benefits was published in 2006 (Fig. 1). Researcher, Jiniti Sasaki, a professor at Hirosaki University. The research showed that black garlic reduced cancer cells in mouse. When the same research was conducted using white garlic, it didn't have the same result".

In the first edition of Wikipedia, the black garlic was introduced likely that "Japanese had developed black garlic in 2005".

However in the revised edition this part of descriptions was completely deleted, and started likely "In Korea, black garlic was introduced as a health product". People therefore believe that the black garlic was created by Korean. This incorrect information is now spreading worldwide.
Black garlic creation was attained by Japanese Mr. Kamimura in Mie Prefecture in 1999 as introduced above, and he had acquired the manufacturing patent of the black from the Japan Patent Office.

\section{Survey of Black Garlic Researches and the Related}

Since the anti-tumor potency of the black garlic had been introduced in the Newspaper 2006 (Fig. 1) and published in journal 2007 [3], the citizens and researchers have fascinated to the black garlic with miracle bio-functions. Especially the post-operative cancer patients have started to ingest expecting metastasis prevention due to enforcement of NK cells activity that had been reported in the animal test.

Currently the average people are making their own black garlic as a hobby by using the electric-rice cooker.

\subsection{What's the Black Garlic? Ugly but Delicious with Beneficial Bio-functions}

Here in a brief introduction of the black garlic's profile appeared at the black garlic home page [4].

"It is learned that the fermented black garlic was made of selected fresh and high-quality raw garlic, using Japanese unique professional approach and carefully processed required for a month which improve the nutrition of the garlic and eliminate the unpleasant odor of garlic to make it easy to accept. Fermented black garlic was researched by Mie

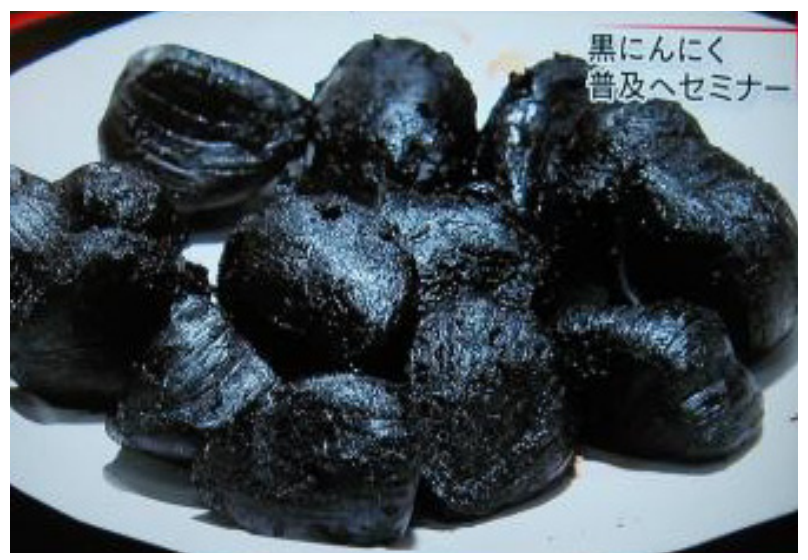

Fig. 2 Black garlic filled with multibio-functions. 


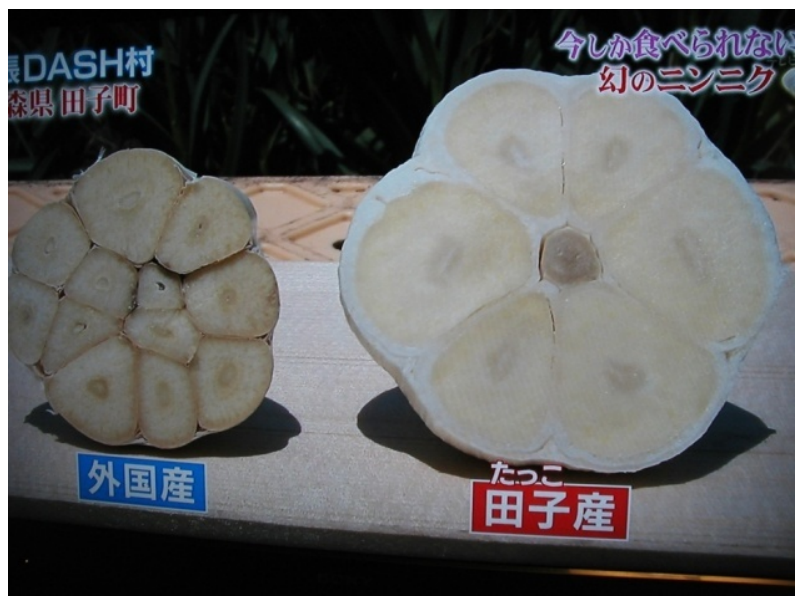

Fig. 3 Feature of the high quality Japanese Garlic called "White Six Cloves" (right) developed by Japanese researcher, and Chinese garlic as reference (left). Japanese one is easily recognizable by its size and number of cloves inside.

Prefecture, Japan in 2003. Professor Sasaki Jin-Ichi, the famous Japanese physician in School of Medicine of Hirosaki University, proved through a mice experiment that the active ingredient of black garlic can improve immunity which has a strong inhibitory on cancer cells".

\subsection{Bio-functions of the Black Garlic}

Beneficial bio-functions of the black garlic were briefly introduced below for understanding true characters.

3.2.1 Tumor Therapeutic Potency Reported by the Hirosaki University

The first report of the bio-functions on the black garlic was independently issued in 2007 from the two universities in Japan, the Hirosaki University [3] (Table 1) and the Fujita Hoken Eisei University [5]. The Hirosaki University's work was on the tumor therapeutic act and the other was on the anti-carcinogenic potency by the Fujita Hoken Eisei University that was briefly introduced in the following 2-2-2 section in this text.

The boiled water extracts of the black garlic attained $50 \%$ cure rate in the mouse model and average tumor size of the non-cured mice was $47.5 \%$ to that of control. By contrast the fresh garlic extracts failed in deletion of transplanted tumor as shown in Table 1, implying surely the presence of therapeutic ingredients in the processed black garlic.

An osteopathic physician Dr. Joseph Mercola introduced the experimental results in his home page [4].

"Another little-known anecdote is that black garlic, which is basically fermented garlic, may be even healthier than other forms. In 2009 mouse study, Japanese researchers found that black garlic was more effective than fresh garlic in reducing size of tumors, for instance. The study was published in the journal Medicinal and Aromatic Plant Science and Technology [3]. In another study, black garlic was found to have twice the antioxidant levels as fresh garlic-the aging/fermenting process appears to double the antioxidants".

3.2.2 Anti-carcinogenic Report from the Fujita Hoken Eisei University in Japan

In 2007 another report on the anti-carcinogenic activity of the black garlic was issued in the journal by the Fijita Hoken Eisei University (Prof. Shimpo's research group) using the 1,2-dimethyl hydrazine (DMH)-induced premalignant lesion model in the rat colon [5]. The outcome was:

Table 1 Tumor therapeutic potency of the back garlic (extracts) against Meth AFibrosarcoma of Balb/c mouse.

\begin{tabular}{llll}
\hline Sample & Dosage & No cured/No mice used & Tumor size of the non-cured against that of control \\
\hline Black g. & $1 \mathrm{mg}$ & $5 / 10$ & $47.5 \%$ \\
Control & $(-)$ & $0 / 5$ & 100 \\
\hline (Reference) & & & $64 \%$ \\
\hline Fresh g. & $5 \mathrm{mg}$ & $0 / 5$ & 100 \\
Control & $(-)$ & $0 / 5$ & \\
\hline
\end{tabular}

*Tumor transplanted mouse was treated by the test samples 3 times injection as therapy after tumor cells transplantation, and left three weeks without further therapy till anti-tumor evaluation. 
"In the 5\% black garlic-fed group for 6 weeks, numbers of premalignant lesion decreased compared with those in the control group given DMH alone. Feeding 5\% black garlic to rats did not affect hematological and serum biochemistry parameters in the tested rats".

The author presently considers that one of the major ingredients for cancer therapeutic and anti-carcinogenic activities is the SAC (S-allyl-L-cysteine) that was created during the garlic processing. This speculation does not necessarily deny other elements association to fight cancer cells.

\subsection{Immune System Boosting and Suppression of Allergic Symptoms}

In previous studies of the tumor therapeutic action of the black garlic results suggested that anti-tumor action could be led via an enhancement of the immune system. To ascertain the presumption an additional experiment was designed, and immune system enhancement was surely confirmed in the black garlic-fed mouse certainly raised as shown in Fig. 4, along with increasing generation of the cytokine IFN,
TNF, NO, and IL-2 (not shown here) [6].

However cytokine IL-4 took different behavior by decreasing its production in the black garlic-fed mouse. Cytokine IL-4 promotes the proliferation and differentiation of B-cells that eventually result in enforcement of allergic symptoms by increasing production of allergic antibody IgE. Lowering of IL-4 production (amount) probably represents the allergic disease suppression. The experimental results in mouse model were well corresponded with the humans clinical cases. It is known that daily taking of the black garlic improved the allergic symptoms in the patients. Additional experiments should be designed to answer this question.

\subsection{Bacteria-Killing Potency}

Anti-bacterial potency was admitted in the extracts of the black garlic against MRSA (Methicillin-Resistant Staphylococcus aureus), enterohemorrhagic E. coli O157, Pseudomonas spp. (a causative agent of opportunistic infection), Candia albicans. However bacteria killing potency was less than that of general fresh garlic. Difference in its activity between them

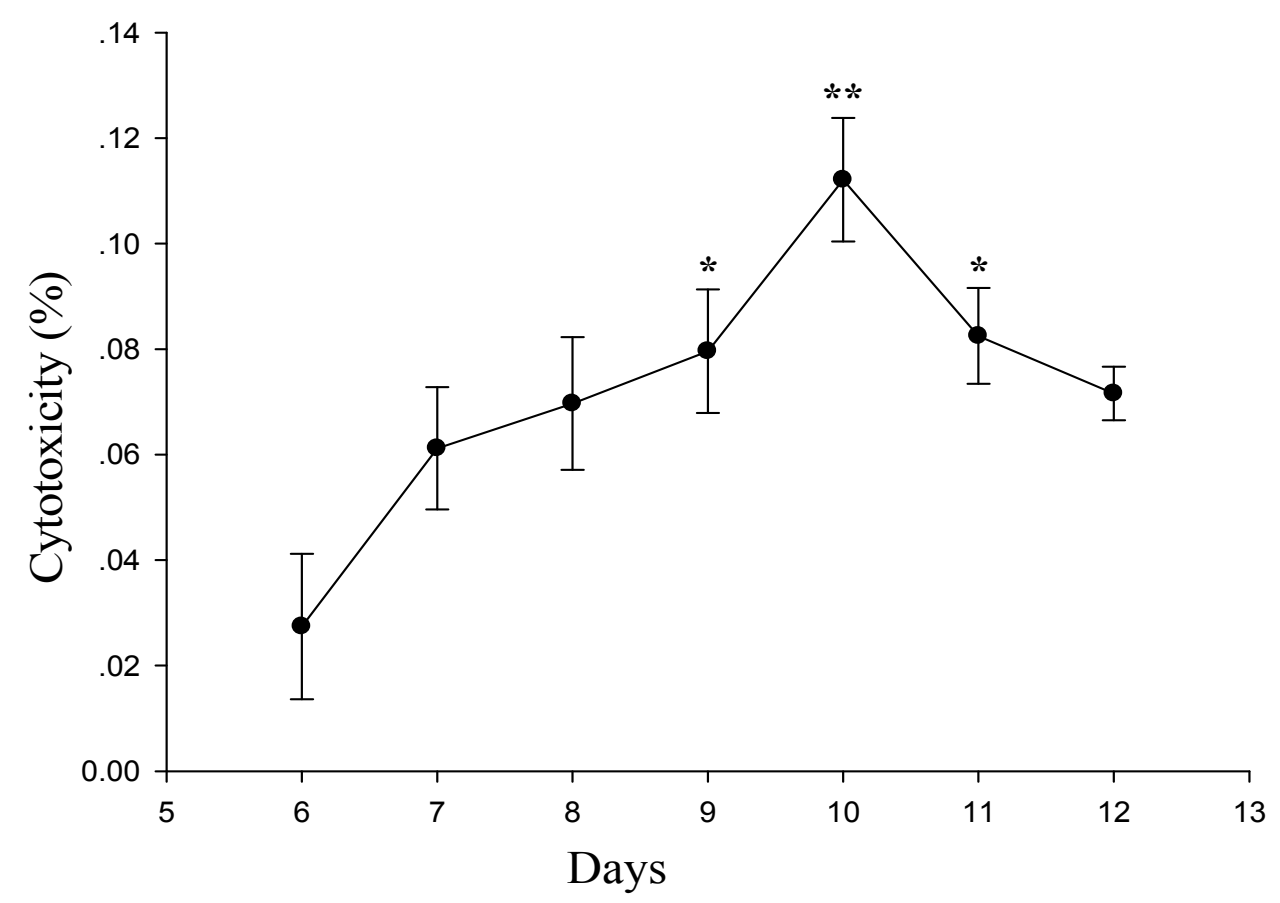

Fig. 4 Increasing NK cells activity in the cell culture system constructed from the black garlic-fed mouse. 


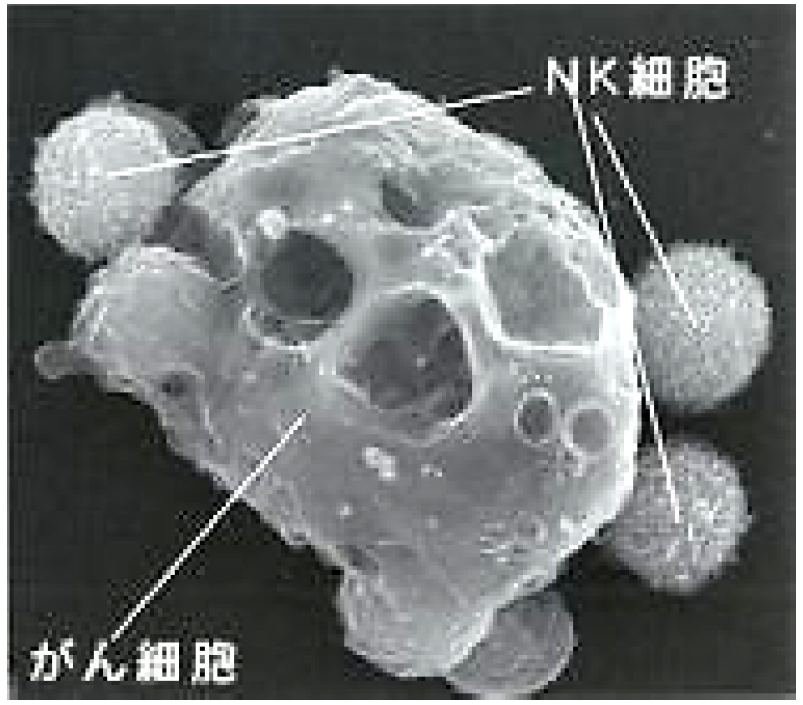

（米国法人蓮見国際研究財団）

(HASUMI International Research Center in USA)

Fig. 5 NK cells fighting against tumor cell to create holes that led tumor cell to death.

might be caused by different amount of volatile allicin contained, which was powerful bacteria killing agent. Great benefit of the black garlic is to have worked to the drug resistant MRSA [3].

\subsection{Antioxidant Act}

Antioxidant either in the form of natural material extracts or chemical constituents are very effective to prevent the destructive process caused by oxidative stress [7]. It is worth noting that the black garlic had the strongest antioxidant properties among a large number of medical plants and vegetables that effectively work as anti-aging and anti-carcinogenic to protect body from harmful chemical attacks (Table 2).

3.6 High Content of GABA in Black Garlic; Improvement of Brain Disorder?

Lately the Aomori Prefectural Industrial Technology Research Center in Japan had found the high content of the GABA ( $\gamma$-aminobutyric acid) at $8-70 \mathrm{mg} / 100 \mathrm{gr}$ in the processed black garlic. It exceeded amount of the germinated brown rice known as the highest content of the GABA at $10 \mathrm{mg} / 100 \mathrm{gr}$.

The compound GABA serves as a neurotransmitter
Table 2 Anti-oxidative potency of black garlic (*RS50\%)

\begin{tabular}{|c|c|c|}
\hline Sample & Black Garlic & Fresh Garlic \\
\hline Japanese & $4.1 \mathrm{mg}$ & $114.9 \mathrm{mg}$ \\
\hline Chinese & 7.3 & 88.5 \\
\hline
\end{tabular}

in central nervous system in humans, and deficiency of it can cause various brain disorder such as Parkinson disease et al [8]. Beneficial bio-functional effects of the black garlic will be expected against the central nervous disorder with no therapeutic or disease preventive ways. Yet the common belief among scientists is that GABA will not cross the blood brain barrier, and not be carried in the brain. This kind of urgent and critical important tasks will soon start at the above center under the financial support of the local government.

Additional new finding was that the pyroglutamic acid that has amnesia-preventive action in rats, improvement of learning in age-associated and alcohol-induced memory loss [9] increased in the black garlic by processing. These new information provided encouraged the black garlic manufacturing companies to do their best for their business.

\subsection{Additional Major Bio-functions Reported up to} Now

- Detoxification activity (Japan 2008);

- Anti-fatigue effect in mouse experiment (Pharmaceutical company Japan 2008)

- Effect against acute alcohol-induced hangover and chronic alcohol-induced liver injury (Korea 2009)

- Decrease the cholesterol level and obesity of body (Korea 2009)

- Control high blood pressure (Australia 2010)

- Regenerative of therapy of burn damaged skin (Clinical study case Malaysia);

- Liver protective effect (Korea 2010);

- Control of diabetics and sugar disease (Korea 2010, India 2013). 


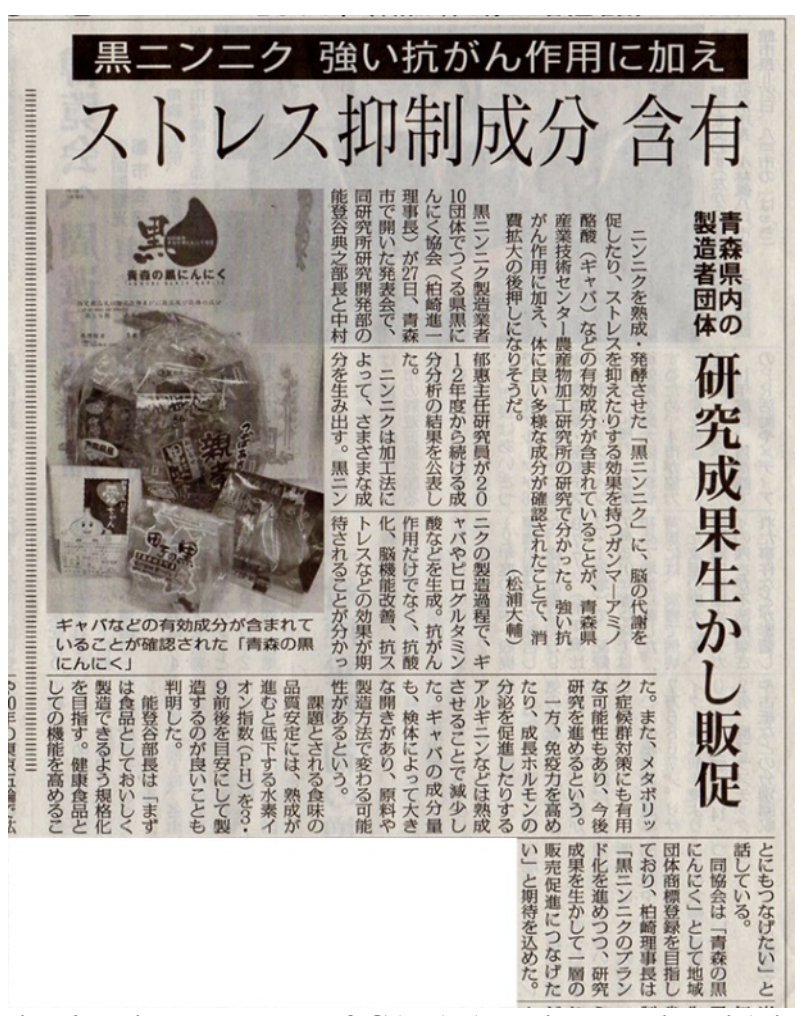

Fig. 6 Higher content of GABA ( $\gamma$-aminobutyric acid) in the black garlic that works to reduce stress (March 28, 2014).

\section{Clinical Case Reports from Clients}

CASE 1: Oil painter Choo Keng Kwang, 81, has been eating around half a bulb of black garlic for the past few months. Mr. Choo who suffers from psoriasis-a skin disease which results in itchy red patches or flaky scales, decided to give the herb a try after seeing a newspaper advertisement for it. He says in Mandarin: "The effect was obvious. After three to four days of consuming black garlic, the red patches disappear. Previously, I've tried many skin creams given by doctors and they were not effective". (www.hardwarezone.com.sg)

CASE 2: Singapore General Hospital dietitian Tan Ai Shan says "Unlike fresh garlic, black garlic is sweeter in taste. The pungent smell and spiciness in fresh garlic is removed during the fermentation process. She pointed to experiments conducted by Japanese researchers in 2007 which suggest that black garlic is more effective in reducing the size of tumor in laboratory mice. The study was published in a
Global Science Book Journal about medicinal plant science".

(www.sgh.com.sg > Home > About Us > Newsroom)

CASE 3: Fermented garlic has greater health benefits than the common varieties, says nutritionist Velumani Deepapriva of the Singapore Nutrition and Dietrics Association. "Especially in improving blood circulation and increasing antioxidant levels in the body". She adds. (beforeitsnews.com/.../aged-black-garlic-a-new-superf o)

CASE 4: Business consultant and part-time marathon runner Edward Goh, 50, started eating black garlic last June to lower in cholesterol level. His cholesterol was high at $250 \mathrm{mg} / \mathrm{dL}$. According to the Singapore Heart Foundation's guide lines, an average adult should maintain his total cholesterol level at less than $200 \mathrm{mh} / \mathrm{dL}$.

(www.sgh.com.sg > Home > About Us > Newsroom)

CASE 5: Mr. Kondoin Guatapara Brazil made the black garlic at home just to distribute his acquaintance prepared by an electric rice-cooker. Local newspaper introduced the black garlic as "Alho Negro" and currently restaurant and supermarket have started to deal in the black garlic. Mr. Kondo recently appears to starte business as the black garlic dealer (Fig. 7).

(www.nikkeyshimbun.com.br/nikkey/html/show/12 0719-61 colonia.html)

Headline; Kondo's black garlic in Guatapara Brazil showed ten times more of anti-oxidative activity than that of general garlic.

\section{Establishment of the Aomori Black Garlic Union to Manufacture High Quality and High Secure Black Garlic in Japan}

On March 2006, the black garlic had made a sensational debut in the field of foods via the Japanese Newspapers and TV. Thereafter an increasing number of companies started to manufacture the black garlic as a new business using advantage of news reported on the black garlic. Some companies had shifted their black garlic plants from Japan to the oversea seeking after inexpensive garlic and low-cost of labors. 


\section{発醭黒にんにくをどうぞ!＝グァタパラ近藤さんが生産・販売 中=抗酸化作用は生の10倍}

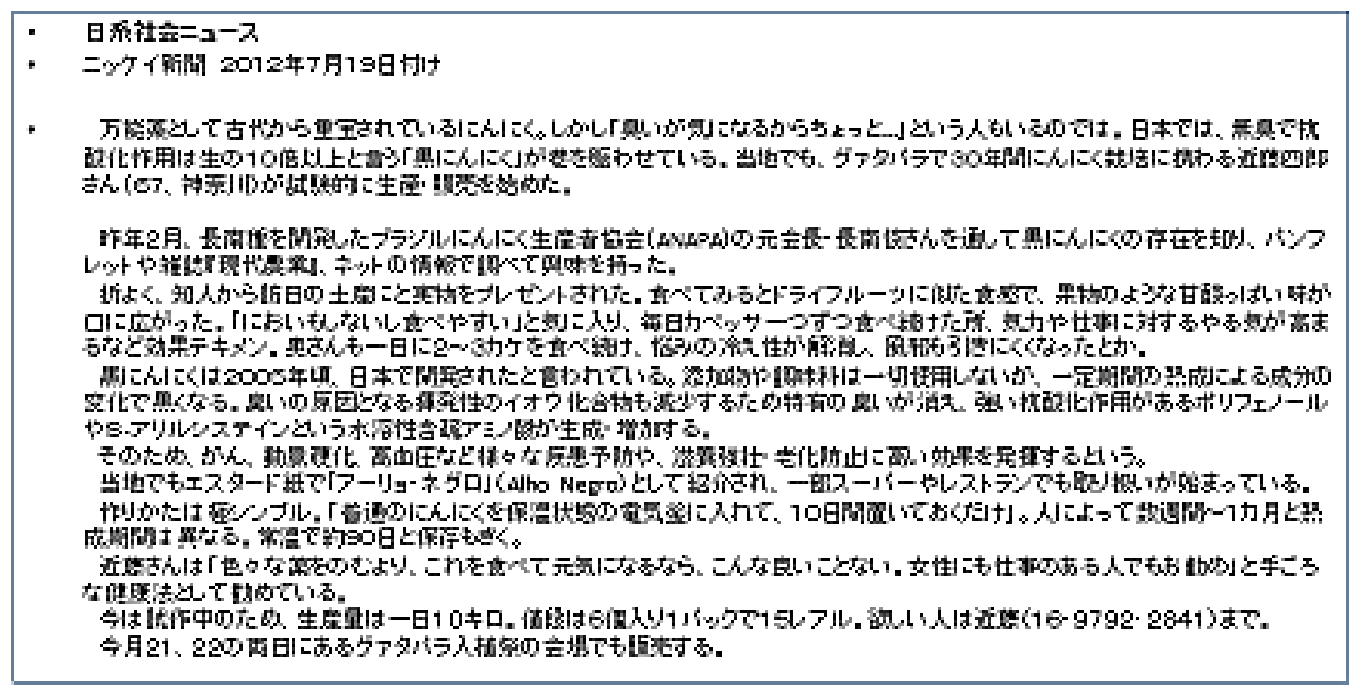

Fig. 7 Japanese-Newspaper in Brazil reported black garlic production by the emigrant Mr. Kondo.

In connection with increase of companies, the product-related troubles had occasionally occurred likely to have used illegally agricultural chemicals that were strictly controlled in our country. Japanese are especially sensitive to these kinds of problems that directly affect family member's health. When purchasing agricultural products at the supermarket they first confirm the country of origin, and read carefully data of chemical analysis placed on for safety. Actually Japanese had experienced in the past severe intoxication affair due to high contamination of the illegal chemicals in the imported products.

Since then, the black garlic companies in Aomori prefecture were considering establishment of "the Aomori Black Garlic Union" to supply the safe products to the citizens [10]. The member's companies in Union were making more of exertions to fulfill the Union's demands to gain citizen's credit. When their products are passed the Union's inspection organized by the third party examinees, the certificate seal below will be given to the company to place on their products (Fig. 8).
The quality inspection system is now effectively working to guarantee the Aomori black garlic quality, along with differentiation of the Union member's products from others. Home-made products currently prevailed among citizens are heterogeneous in quality, color, testy, and they are likely to be a half-raw material (Fig. 9) due to the incomplete processing manners. These sorts of the defectives are hard to eat with the remained pungent odor, lacking of sweetness, and will result in loss of the black garlic customers.

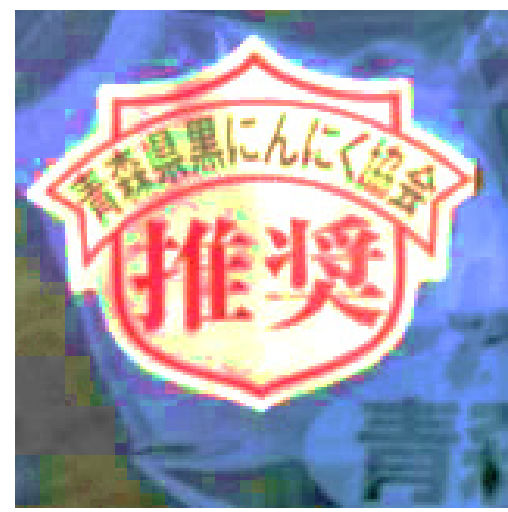

Fig. 8 "Authorized Warranty Emblem" issued by "Black Garlic Society of Aomori". This seal secures "Safety and Security of the black garlic". 


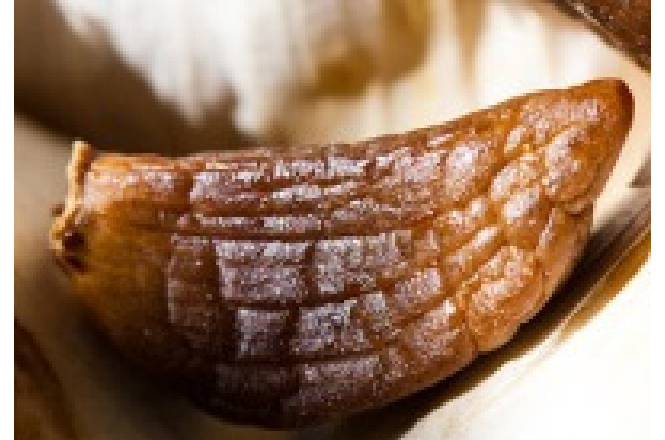

Fig. 9 Insufficient processing manners created this sort of defective (by Caroline Hatchett).

At that time of the Fukushima Nuclear Power Plant explosion, the radioactive contamination assessment

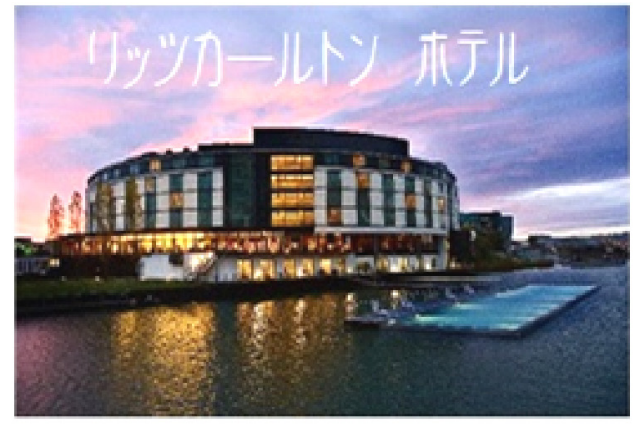

ドインフォルクスワーゲ

本社工場のある街、

ヴォルつスブルグをるる最高級ホテル リуンカールトォォテル。 standard on foods had not enacted in Japan. After plants explosion the rumor damages rapidly grew and the citizens hesitated to purchase the agricultural and fisheries products shipped from Fukushima and neighboring prefectures [11]. Foreigners living in Tokyo and around had evacuated immediately to the home countries, and some of them never came back again. To clear up the rumor damages of radioactive pollution on foods the public inspection center started to measure all foods before shipping to offer people security with "the Radiological Testing Inspection Certificates". The black garlic was also not exception

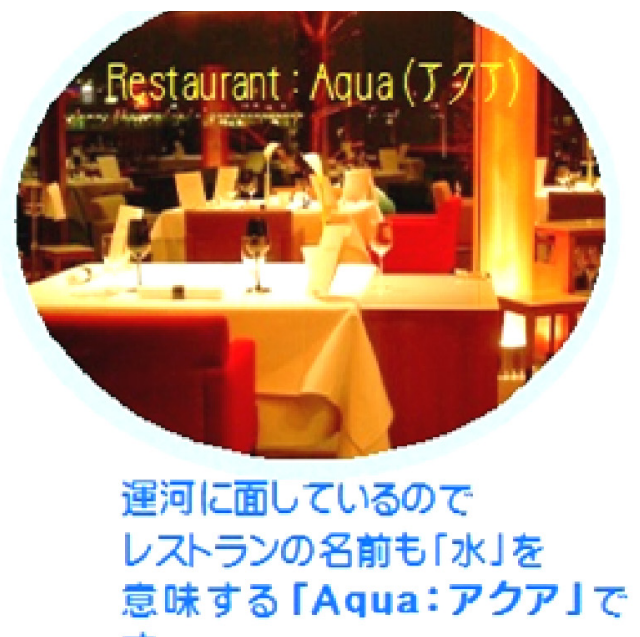

Fig. 10 “Takko Shoji's products" are served at cuisine of the 3 Star Hotel in German.

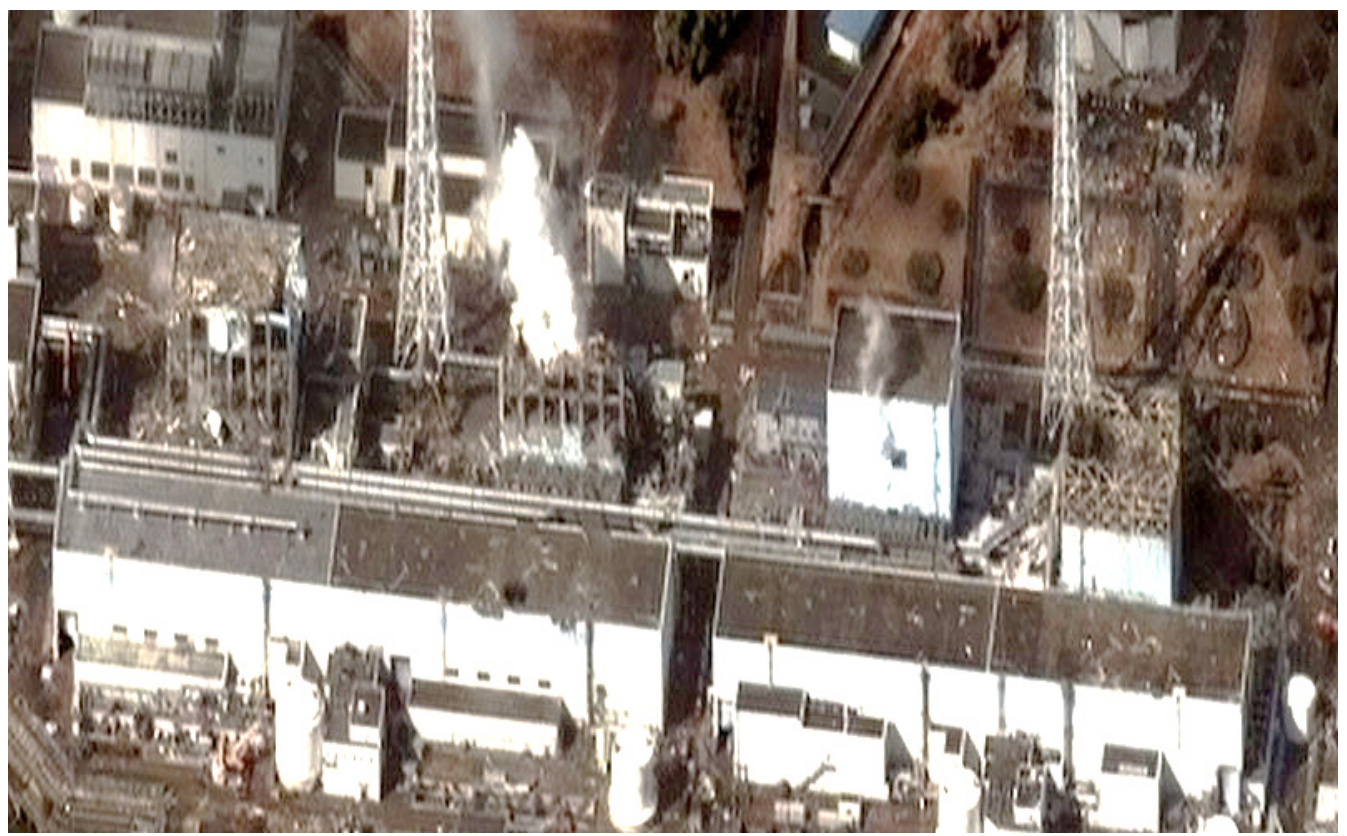

Fig. 11 Nuclear power plant explosion due to disorder of cooling system caused by Tsunami. 


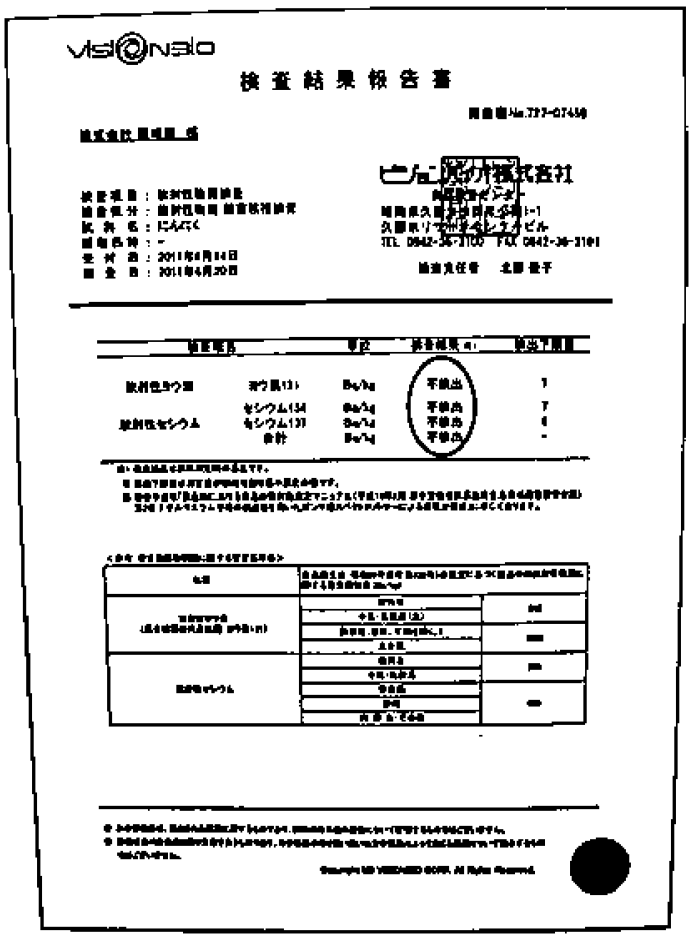

Fig. 12 Safety proof certificate issued by the government authorized inspection center in Japan against the radioactive pollution of the black garlic.

even in Aomori prefecture, where was located in 500 km north from Fukushima plants. The Union member's companies voluntarily measured radioactivity on their products, and shipped to the markets along with the safe certificate as shown in Fig. 12.

\section{Discussion}

The novel type of vegetable, the black garlic, rose up its name among the citizens in both domestic and foreign countries because of plenty of beneficial bio-functions as listed in the text along with the personal experiences. At the moment the black garlic is less recognizable even among the scientific researchers, and most of them know nothing about it.

However its popularity is increasing among the citizens and scientists, and some scientists are initiating experiments on the black garlic currently. One of the latest new findings was the higher content of the GABA ( $\gamma$-amino-butyric acid) in the processed black garlic.
This compound is critical important as a neurotransmitter in central nervous system as described above. Alzheimer and Dementia are representative brain disorders at the aged. Deficiency of GABA in brain causes various mental diseases as anxiety disorders likely to be panic attacks, headaches, Parkinson disease, and can also cause depression, insomnia, and epilepsy. Japanese researchers lately initiate bio-functional works of the black garlic for restoration of the damaged nervous systems.

Researchers in broad areas should co-work to try to find new functional ingredients in the natural product [12] to overcome the intractable diseases such as cancer, brain disorder et al.

Additionally ubiquitous urgent requirement in the black garlic is the organization of the national and/or international association to establish the safety guideline of the products to avoid the unexpected problems.

\section{Conclusion}

Present state of the novel vegetable "Black Garlic" was reviewed from both aspects of scientific and business fields. An increasing number of the black garlic companies are now growing to cultivate their market places around the world repeating the heat competition. Excessive competition eventually resulted in sales at low price of the defective products in the markets by ignoring of safe and security of the products. To avoid this kind of the problems experienced in the past, the black garlic related companies have to perform their duties conscientiously to contribute to the nation's health promotion.

\section{References}

[1] "Fermented Black Garlic" (in Japanese). Accessed April 23, 2014. http://www.yojoan.com/page/3.

[2] Sato, Y. 2014. "Does Black Garlic a Day Keep the Doctor away." Accessed April 23, 2014. www.Discoverjapannow.wordpress.com/.../does-black-g arlic-a-day. 
[3] Sasaki, J., Lu, C., Machiya, E., Tanahashi, M., and Hamada, K. 2007. "Processed Black Garlic (Allium sativum) Extracts Enhance Antitumor Potency Against Mouse Tumors." Medicinal and Aromatic Plant Science and Biotechnology (Global Science Books) 1 (2): 278-81.

[4] Mercola, J. 2014. "Eating Garlic May Help Ward off Colds and Flue-Health." Accessed June 5, 2014. articles.mercola.com/sites/articles/archive/.../garlic-benefi ts.asp.

[5] Kaneko, T., Chihara, T., Beppu, H., Tomatsu, A., Sonoda S., and Shimpo, K. 2007. "Inhibitory Effect of Fermented Black Garlic on 1, 2-dimethylhydrazine-induced Premalignant Lesion in the Rat Colon." Fujita Gakuen Igakkaishi (in Japanese) 31 (2): 143-7.

[6] Wang, D., Feng, Y., Liu, J., Yan, J., Wang, M., Sasaki, J., and Lu, C. 2010. Medicinal and Aromatic Plant Science and Biotechnology (Global Science Books) 4 (2): 37-40.

[7] Zengin, G., Cakmak, Y. S., Guler, G. O., and Aktumsek, A. 2011. "Antioxidant Properties of Methanolic Extract and Fatty Acid Composition of Centaurea Urvillei DC." Rec Nat Prod 5: 123-32.

[8] Denver Naturopathic Clinic. 2015. "Gamma-Amino Butyric Acid.” Accessed March 10, 2015. www.denvernaturopathic.com/news/GABA.html.

[9] Akhilesh, K. A., and Bachhawat, A. K. 2012. "Pyroglutamic Acid: Throwing Light on a Lightly Studied Metabolitre.” Current Science 102 (2): 288-97.

[10] Aomori Black Garlic Association. 2013. "New Wave of Garlic, Black Garlic.” Accessed June 20, 2014. http://www.96229jp.com/bg/index.html.

[11] Sasaki, J. 2012. "Earthquake-Caused Tsunami, Infection and Nuclear Plant Accident in Japan." In Proceedings of the First AFSSA Conference on Food Safety and Food Security, 1-10.

[12] Sasaki, J. 2006. "Bioactive Phytocompounds and Products Traditionally Used in Japan." In Modern Phytomedicine: Turning Medical Plants into Drugs, edited by Ahmad, I., Aqil, F., and Owais, M. WILEY-VCH Verlag GmbH \& Co. KG aA. 